\title{
"The Fama and French three-factor model in developing markets: evidence from
}

the Chinese markets"

\begin{tabular}{|c|c|}
\hline AUTHORS & $\begin{array}{l}\text { Man Li (D https://orcid.org/0000-0002-2079-8625 } \\
\text { Michael Dempsey (D https://orcid.org/0000-0002-9059-0416 }\end{array}$ \\
\hline ARTICLE INFO & $\begin{array}{l}\text { Man Li and Michael Dempsey (2018). The Fama and French three-factor model } \\
\text { in developing markets: evidence from the Chinese markets. Investment } \\
\text { Management and Financial Innovations, 15(1), 46-57. } \\
\text { doi:10.21511/imfi.15(1).2018.06 }\end{array}$ \\
\hline DOI & http://dx.doi.org/10.21511/imfi.15(1).2018.06 \\
\hline RELEASED ON & Tuesday, 23 January 2018 \\
\hline RECEIVED ON & Friday, 26 May 2017 \\
\hline ACCEPTED ON & Tuesday, 28 November 2017 \\
\hline LICENSE & $\begin{array}{l}(c)) E Y \\
\text { This work is licensed under a Creative Commons Attribution } 4.0 \text { International } \\
\text { License }\end{array}$ \\
\hline JOURNAL & "Investment Management and Financial Innovations" \\
\hline ISSN PRINT & $1810-4967$ \\
\hline ISSN ONLINE & $1812-9358$ \\
\hline PUBLISHER & LLC "Consulting Publishing Company "Business Perspectives" \\
\hline FOUNDER & LLC "Consulting Publishing Company "Business Perspectives" \\
\hline
\end{tabular}

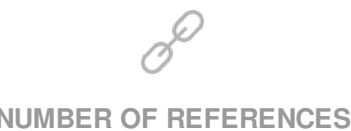

25

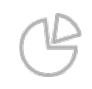

NUMBER OF FIGURES

0

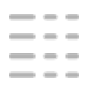

NUMBER OF TABLES

7

(C) The author(s) 2023. This publication is an open access article. 


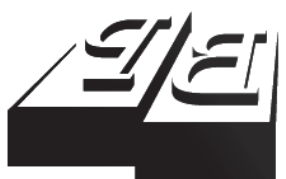

BUSINESS PERSPECTIVES

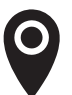

LLC "CPC "Business Perspectives" Hryhorii Skovoroda lane, 10, Sumy, 40022, Ukraine

www.businessperspectives.org

Received on: $26^{\text {th }}$ of May, 2017 Accepted on: $28^{\text {th }}$ of November, 2017

(C) Man Li, Michael Dempsey, 2018

Man Li, Dr., Head Tutor, Business School, University of Western Australia, Australia.

Michael Dempsey, Professor, Faculty of Finance and Banking, Ton Duc Thang University, Vietnam.

\section{(c) (i)}

This is an Open Access article, distributed under the terms of the Creative Commons Attribution 4.0 International license, which permits unrestricted re-use, distribution, and reproduction in any medium, provided the original work is properly cited.

Man Li (Australia), Michael Dempsey (Vietnam)

\title{
THE FAMA AND FRENCH THREE- FACTOR MODEL IN DEVELOPING MARKETS: EVIDENCE FROM THE CHINESE MARKETS
}

\begin{abstract}
The authors study the Fama and French three-factor (FF-3F) model in relation to a developing market. To this end, they consider Chinese stock markets over the period 1995-2008, which is to say, over a period when these markets are recognized as "developing" markets influenced by speculative activity. The authors find that the model appears to be working as a form of "principal component analysis for the determinants of stock price formation with book-to-market $(\mathrm{B} / \mathrm{M})$ as the "variable of choice" on account of that it captures the earnings-to-price $(\mathrm{E} / \mathrm{P})$, cash-flow-to-price $(\mathrm{C} / \mathrm{P})$ and sales-to-price $(\mathrm{S} / \mathrm{P})$ variables while remaining largely uncorrelated with firm size (whereas E/P, C/P and S/P are themselves positively correlated with firm size). The variables, however, are unrelated to risk as represented by market exposure, volatility, or leverage.
\end{abstract}

\section{Keywords}

JEL Classification

\section{INTRODUCTION}

The fundamental nature of factor models such as the Fama and French three-factor (FF-3F) model remains unclear. We ask: Can the model be justified as a risk-based model as its authors contend? Or is it a model that on aggregate has successful captured long-term investor cycles in preferences for value and growth stocks? In this paper, we avail of a period in Chinese stock market history dominated by speculative trading to test the nature of the three-factor model in developing (retail dominated) markets. We provide evidence that the model succeeds as a form of "principal component analysis" whose factors are efficient in capturing a range of variables that are predictive of share price movements. The variables, however, are unrelated to risk as represented by market exposure, volatility, or leverage.

The FF-3F model introduced two variables in addition to beta, which, they claimed, administered most of the "heavy work" in explaining historical stock price movements. These variables are the market equity (ME) value or size of the underlying firm, and the ratio of the book value of the firm's common equity to its market equity value $(B / M)$, which together "provide a simple and powerful characterization of the cross-section of average stock returns for the period 1963-1990" (Fama \& French, 1992, p. 429). The authors concluded that "if stocks are priced rationally, the results suggest that stock risks are multidimensional" (Fama \& French, 1992, p. 428).

Although the FF-3F model is now widely applied in the context of det veloping markets, the underlying explanation for the model's success 
remains an open issue. Thus, although Fama and French $(1993,1995,1996)$ argue that higher returns are compensation for holding higher fundamental risk, in line with the inter-temporal capital asset pricing model (ICAPM) of Merton (1973) or the arbitrage pricing theory (APT) of Ross (1976), their interpretation remains controversial. Lakonishok, Shleifer, and Vishny (1994), for example, suggest that investors appear to consistently underestimate future growth rates for value stocks (stocks with high book-equity-to-market-equity (B/M), high earnings-to-price (E/P) and high cash-flow-to-price $(\mathrm{C} / \mathrm{P})$ ) and therefore underprice them. This results in value stocks outperforming growth stocks.

Our main contributions to this debate are as follows. First, we document that the FF-3F model succeeds in describing the cross-section of stock returns in China during the period prior to the global financial crisis when the Chinese markets were characterized as "developing markets" dominated by retail and speculative traders. The success of the model in describing the cross-section of stock returns in this period suggests that the model's success can be related to market speculative activity.

In seeking to demonstrate the above, we find that a plausible explanation for the small firm size effect is a genuine risk exposure, in that small firms are especially sensitive to market downturns, that is, they have high betas. However, stocks with high $\mathrm{B} / \mathrm{M}$ value outperform low $\mathrm{B} / \mathrm{M}$ stocks in both up- and down-markets. Thus, low B/M firms cannot be characterized as "growth" firms that prosper in optimistic (up-market) periods. In addition, we are unable to provide a risk-return based explanation for the outperformance of high $\mathrm{B} / \mathrm{M}$ stocks in terms of either higher leverage or volatility (the correlations being in the opposite direction). It rather appears that higher $\mathrm{B} / \mathrm{M}$ values capture higher earnings-toprice $(\mathrm{E} / \mathrm{P})$, cash-flow-to-price $(\mathrm{C} / \mathrm{P})$ and sales-to-price $(\mathrm{S} / \mathrm{P})$ ratios as indicators of the underlying stock's undervaluation, and that these signals are recognized by investors with the outcome that stock prices respond upward.

We provide evidence that the FF-3F model represents a form of "principal component" analysis of the determinants of stock price formation (rather than a theoretical model). We interpret $\mathrm{B} / \mathrm{M}$ as the "variable of choice" in combination with firm size in such a factor model. This is because B/M (which captures the $\mathrm{E} / \mathrm{P}, \mathrm{C} / \mathrm{P}$ and $\mathrm{S} / \mathrm{P}$ variables) is largely uncorrelated with firm size (whereas $\mathrm{E} / \mathrm{P}, \mathrm{C} / \mathrm{P}$ and $\mathrm{S} / \mathrm{P}$ are themselves positively correlated with firm size).

Studies focused on the asset pricing mechanism in Chinese stock markets remain sparse. A notable exception is Eun and Huang (2007). Although these authors do not apply the FF-3F model directly, they document that firm size and the book-to-market ratio are systematically related to stock returns. They are, however, unable to report evidence of a risk-return relationship. They find, instead, that market risk is not significantly priced and that there is a significantly negative relationship between expected returns and stock volatility. Our paper builds on the Eun and Huang (2007) study, focusing on the applicability of the FF-3F model in the Shanghai (SHSE) and Shenzhen (SZSE) stock exchanges, over the period from 1995 to 2008.

The remainder of this paper is arranged as follows. In section 1, we present some key background features of extant research in Chinese equity markets. In section 2, we present our data and methodology. section 3 presents our findings, while the final section sets forth our conclusions.

\section{PRIOR STOCK MARKET RESEARCH IN CHINA}

The literature on Chinese stock market has focused mainly on the effect of privatization, the underpricing of IPOs, and price differentials among different classes of shares (Qi, Wu, \& Zhang, 2000; Sun \& Tong, 2000, 2003; Li, Yan, \& Greco, 2006; Ma \& Faff, 2007). Only recently has the behavior of stock returns relative to fundamental variables received special attention. The study by Eun and Huang (2007) reports that (a) both firm size and $\mathrm{B} / \mathrm{M}$ are related to 
stock returns in the direction consistent with the FF$3 \mathrm{~F}$ model, and (b) market risk is not priced. Eun and Huang (2007) also report that investors are willing to pay a liquidity premium and value A-shares more if there are offshore counterparts; and there is no January effect, but August sees the highest average returns of the year. They conclude their study by stating, "Overall, given various imperfections in China, stocks in the Chinese market seem to be priced in a rather rational manner, in spite of the widespread perception to the contrary" (p. 478).

The Chinese stock market has been negatively correlated with the US market (Kang, Liu, \& Ni, 2002). It has grown rapidly since its inception in the early 1990s and is now among the most important emerging markets ${ }^{1}$. The total capitalization of the SHSE and the SZSE has risen from 10.77 billion RMB (beginning 1993) to around 12.14 trillion RMB by year-end 2008, and the number of listed firms has increased from 13 to 1,604 over the same period (CSMAR data). This rapid growth is due largely to the steady flow of newly listed firms and the vast reduction in state ownership. Almost all publicly listed firms in China were formerly large and medium state-owned enterprises (SOEs). An initial purpose of opening the SHSE and SZSE was to raise funds for SOEs. The ownership structure of former SOEs has thus resulted in a mixed structure among listed firms, a distinct characteristic of the Chinese market (Sun \& Tong, 2003). Consequently, there are several types of shares in the Chinese stock market: state shares and legal person shares, which cannot be traded or owned by the central government, local governments, or government-owned enterprises; A-shares, traded by domestic investors, Qualified Foreign Institutional Investors; and B-shares, issued to foreign investors ${ }^{2}$. Shareholders of non-tradable shares are entitled to the same voting and cash-flow rights as holders of tradable shares, but they cannot trade their shares publicly even if the firm is listed
(Poon, Firth, \& Fung, 1998; Li, Yan, \& Greco, 2006). About two-thirds of Chinese shares were non-tradable prior to the non-tradable share reform of 2005 (Beltratti \& Bortolotti, 2006) ${ }^{3}$.

Most listed firms are former SOEs, giving rise to severe agency problems. Managers may have little incentive to enhance the quality of listed firms; and as the primary regulator of the Chinese equity market, the China Securities Regulatory Commission (CSRC) is reluctant to supervise listed firms, although it does investigate market manipulation and speculation ${ }^{4}$. Infractions, including accounting fraud and providing false or misleading securities information, have damaged investor confidence (Allen, Qian, Qian, \& Zhao, 2008; Li, 2008). Furthermore, Chinese investors' trading experience and level of sophistication in the period of study is likely to be less than that of investors in developed markets, and most individual investors in China have only short-term investment objectives, in contrast to the relative long-term focus of foreign investors (Kang, Liu, \& Ni, 2002; Ng \& Wu, 2006, 2007).

\section{DATA AND RESEARCH METHOD}

\subsection{Data and variable description}

The data for this study are taken from two sources. We obtain monthly stock returns, market capitalization, number of listed shares, the risk-free rate, and monthly market returns from the China Stock Market and Accounting Research Database (CSMAR), designed and developed by GTA Information Technology. The risk-free rate is proxied by the monthly return on one-year fixed deposits and the market return is proxied by the monthly value-weighted, aggregated market return construct-

1 To complement the two main exchanges, the Small and Medium (SME) Board was opened in June 2004 within the SZSE. The SME affords small and medium enterprises lower entry barriers listing, especially for new high-tech firms. Similarly, the Special Treatment (ST) Board was established in 2001 for delisted firms from both the SHSE and SZSE (http://www.world-exchanges.org; http://www.szse.cn; http:// www.sse.com.cn).

2 Chinese firms are also allowed to issue shares in overseas stock markets, such as H-shares listed on the Hong Kong Stock Exchange and N-shares listed on the New York Stock Exchange (Poon et al., 1998; Sun \& Chong, 2007).

3 To address problems of non-tradable shares, Chinese authorities made several attempts to release such shares to the public. The first two attempts in 1999 and 2001 failed rather badly. On April 29, 2005, the Chinese authorities responded by launching a new structural reform program to encourage all A-share-listed firms to gradually transform non-tradable shares into tradable shares (Beltratti \& Bortolotti, 2006; Lu, Balatbat, \& Czwernkowski, 2008).

4 Controlling shareholders of SOEs are often the State-owned Assets Supervision and Administration Commission (SASAC) and the Ministry of Finance (MOF), which are also ministry-level agencies of State Council, making it difficult for the CSRC to enforce independent regulation over listed firms ( $\mathrm{Li}, 2008)$. 
Table 1. Descriptive statistics for the Chinese A-share market over the period January 1995 December 2008

\begin{tabular}{|c|c|c|c|c|c|}
\hline Year & $\begin{array}{c}\text { Average } \\
\text { number of } \\
\text { listed stocks }\end{array}$ & $\begin{array}{l}\text { Average total market } \\
\text { value (RMB billion) }\end{array}$ & $\begin{array}{c}\text { Average market value } \\
\text { of tradable shares } \\
\text { (RMB billion) }\end{array}$ & $\begin{array}{c}\text { Average trading } \\
\text { volume }\end{array}$ & $\begin{array}{c}\text { Average value of } \\
\text { shares traded (RMB } \\
\text { billion) }\end{array}$ \\
\hline 1995 & 287 & 333.78 & 79.68 & $68,095.67$ & $395,816.63$ \\
\hline 1996 & 311 & 952.87 & 252.20 & $246,511.49$ & $2,105,331.43$ \\
\hline 1997 & 514 & $1,731.66$ & 488.18 & $247,129.84$ & $3,029,521.18$ \\
\hline 1998 & 719 & $1,934.15$ & 554.78 & $209,159.57$ & $2,340,946.26$ \\
\hline 1999 & 825 & $2,630.52$ & 797.74 & $280,931.81$ & $3,104,367.78$ \\
\hline 2000 & 923 & $4,780.02$ & $1,555.06$ & $456,047.65$ & $6,029,815.75$ \\
\hline 2001 & 1060 & $4,254.66$ & $1,332.81$ & $246,836.40$ & $3,327,976.92$ \\
\hline 2002 & 1135 & $3,768.46$ & $1,177.06$ & $286,056.50$ & $2,714,820.76$ \\
\hline 2003 & 1198 & $4,168.22$ & $1,236.36$ & $399,015.12$ & $3,124,825.11$ \\
\hline 2004 & 1262 & $3,654.02$ & $1,106.64$ & $567,129.22$ & $4,156,695.77$ \\
\hline 2005 & 1350 & $3,184.68$ & $1,003.28$ & $646,893.54$ & $3,108,738.78$ \\
\hline 2006 & 1352 & $8,891.57$ & $2,384.67$ & $1,580,656.28$ & $8,920,308.17$ \\
\hline 2007 & 1390 & $32,556.24$ & $9,081.83$ & $3,568,212.49$ & $45,474,251.16$ \\
\hline 2008 & 1497 & $14,824.85$ & $4,458.56$ & $2,387,029.33$ & $26,551,492.14$ \\
\hline
\end{tabular}

Note: This table provides an overview of the growth of the Chinese stock market from 1995 through 2008, including the number of listed firms, total market capitalization of outstanding shares (tradable and non-tradable), market capitalization of tradable shares, trading volume, and value of shares traded.

ed using A-share stocks listed on the SHSE and the SZSE in the CSMAR databases ${ }^{5}$. Accounting data for total shareholder equity, total liabilities, operating revenue, net profit, and net cash flows are also obtained from the CSMAR Database. We measure size as: (1) the market capitalization of total outstanding shares (tradable and non-tradable) in the calculation of various ratio-based variables, and as (2) the market capitalization of tradable shares in the portfolio and regression analyses. Book value of equity, debt, sales, earnings, and cash flows are defined, respectively, as total shareholder equity, total liabilities, operating revenue, net profit, and net cash flows from operating activities. Total volatility of a stock is defined as monthly variance of returns, which is measured at monthly frequencies. Our sample is characterized by having a roughly equal number of up-market and down-market months, along with high levels of stock turnover. These characteristics provide a rich setting for testing the performance of the FF-3F model against a range of scenarios that are likely to differ markedly from those in large developed markets such as the US.
Tables 1 and 2 present the total number of listed stocks and the market capitalization for both the A-share market and the B-share market from January 1995 to December 2008. Descriptive statistics presented in Table 1 summarize the growth of the Chinese A-share stock market over the sample period. Table 2 highlights the contrast between returns over up-market and down-market months.

There are two reasons for commencing the sample in January 1995. First, the number of listed stocks is quite small in the early years. Second, the Company Law that became effective in 1994 standardized the information disclosure of listed companies, so that accounting statements of listed companies are more structured from $1995^{6}$.

To be comparable with similar studies, for example, Eun and Huang (2007), we define book equity as total shareholder equity, debt as total liabilities, sales as operating revenue, earnings as net profit, and cash flow as net cash flow from operating activities. In contrast with Eun and Huang (2007) and Fama and

5 We restrict our analysis to the A-share market because the number of B-share-listed firms is much lower, B-share market capitalization is much smaller, and liquidity is much lower than the A-share market. At the end of 2008, the market capitalization of the A-share stock market was around 8.94 billion RMB and the number of A-share stocks was 1,407, while the market capitalization of the B-share market was about 0.25 billion RMB, with only 106 B-share stocks (CSMAR, 2008).

6 On November 30, 1992, with the approval of the State Council, the Minister of Finance signed and issued the first set of accounting standards for China - "Accounting Standard for Business Enterprises". All business enterprises were required to comply with the standards beginning July 1, 1993. In an attempt to standardize the format of statements, the CSRC released "Regulation Number Two on Information Disclosure by Listed Companies in 1994 - The Contents and Formats of Annual Reports" (Draft), which stipulated the contents, format and timing of declarations of annual reports. 
Table 2. Basic characteristics for down-markets, up-markets and full sample over the period January 1995 - December 2008

\begin{tabular}{l|c|c|c}
\hline & Down-market period & Up-market period & Whole period \\
\hline Number of months & 80 & 88 & 168 \\
\hline Average monthly return & - & - & - \\
\hline Mean & -0.0623 & 0.0823 & 0.0134 \\
\hline Maximum & -0082 & 0.3638 & 0.3638 \\
Minimum & -0.2649 & 0.0027 & -0.2649 \\
Std & 0.0527 & 0.0741 & 0.0971 \\
Total market value (RMB billion) & $5,254.09$ & $5,656.08$ & $5,464.66$ \\
Market value of tradable shares (RMB billion) & $1,572.14$ & $1,734.51$ & $1,657.19$ \\
\hline
\end{tabular}

Note: This table reports the number of months for each market condition, average monthly return (mean, maximum, minimum, and standard deviation), total market capitalization and market capitalization of tradable shares.

French (1992), who measure the fundamental variables on an annual level, we follow Chan, Hamao, and Lakonishok (1991) in our regressions and measure fundamental variables on a monthly level in relation to moving stock prices.

To be broadly consistent with most published studies, several filters are applied. First, the accounting data must be matched with the corresponding trading data. To this end, we restrict ourselves to those firms that report a monthly return and market capitalization, as well as accounting data on total equity, total liabilities, earnings, cash flows and operating revenues at the end of the preceding year. This filter eliminates $8.6 \%$ of the initial sample. Second, firms that have negative book value of equity are excluded from the final sample (1.2\% of the initial sample). However, stocks with negative earnings or negative cash flows are included in our sample (approximately 5\% of monthly observations contain negative earnings, and about $10 \%$ of observations contain negative cash flows). To measure volatility, we require stock returns for the previous 24 months, which eliminates 5,840 monthly observations. Together, our filters eliminate 15,112 observations, so that our final sample consists of 1,661 stocks with 140,401 monthly observations. Finally, the subsample after the variance filter is applied comprises 1,458 stocks and 134,561 monthly observations.

\subsection{Methodology}

To investigate the explanatory power of the FF-3F model in the Chinese markets, we apply (1) regression analyses, whereby the FF-3F is tested directly, and (2) portfolio analysis, in which portfolios are formed based on double sorts in the size and book-to-market dimensions, as well as other diagnostic variables, and the returns of each portfolio are investigated. These analyses are performed at the monthly level. Analysis of the FF-3F model is followed by an analysis of the relations between return performance and stock volatility. These analyses are conducted for the overall market, as well as for up-market and down-market months separately.

Following Fama and French (1993), our test assets are 25 size-B/M portfolios. A-share stocks are first sorted into quintile portfolios based on their market capitalization (market value of tradable shares) in June of year $t$. These stocks are independently sorted into quintile $\mathrm{B} / \mathrm{M}$ groups at the end of December of yeart -1 . The 25 size-B/M portfolios are constructed as intersections of the size and $\mathrm{B} / \mathrm{M}$ groups. Valueweighted monthly returns on the portfolios are calculated from July of each year $t$ to June of year $t+1$. We perform this analysis for the whole sample, as well as for the up-market and downmarket subsamples.

We calculate monthly returns on SMB and HML in the conventional way. Stocks are allocated into two groups (small (S) or big (B)), based on the median of June market equity (stock price multiplied by tradable shares). The stocks are also independently sorted into three $\mathrm{B} / \mathrm{M}$ groups (low (L), medium $(\mathrm{M})$, or high $(\mathrm{H})$ ), based on the 30:40:30 split developed by Fama and French. SMB is calculated as the difference in average returns between small-stock portfolios (S/L, S/M and S/H) and bigstock portfolios $(\mathrm{B} / \mathrm{L}, \mathrm{B} / \mathrm{M}$ and $\mathrm{B} / \mathrm{H})$, while $\mathrm{HML}$ 
is calculated as the difference in average returns between high- $\mathrm{B} / \mathrm{M}$ portfolios $(\mathrm{S} / \mathrm{H}, \mathrm{B} / \mathrm{H})$ and low$\mathrm{B} / \mathrm{M}$ portfolios $(\mathrm{S} / \mathrm{L}, \mathrm{B} / \mathrm{L})$.

The FF-3 Fregression specification is given by:

$$
\begin{aligned}
& R_{p t}-R_{f t}=\alpha_{p}+b_{p}\left(R_{M t}-R_{f t}\right)+ \\
& +S_{p} S M B_{t}+h_{p} H M L_{t}+\varepsilon_{p} .
\end{aligned}
$$

In addition to standard tests, we examine the relationship between total volatility and average stock returns for both up-market and down-market conditions. At the end of each month from January 1995 to December 2008, stocks are sorted into quintiles based on total volatility in the preceding month (using both monthly and daily returns). Quintile 1 (quintile 5) contains stocks with the lowest (highest) total volatility. We also sort stocks into quintiles by market capitalization (market value of tradable shares) in each volatility quintile. Similar analysis is performed with each of the volatility quintiles sorted into quintiles of book-to-market. Equal-weighted monthly returns and average values of characteristic variables (size, $\mathrm{B} / \mathrm{M}, \mathrm{S} / \mathrm{P}, \mathrm{D} / \mathrm{E}, \mathrm{E} / \mathrm{P}$, or $\mathrm{C} / \mathrm{P}$ ) of each portfolio are also calculated.

\section{EMPIRICAL RESULTS}

The average equally-weighted monthly returns of $5 \times 5$ portfolios formed on size and $\mathrm{B} / \mathrm{M}$ quintiles are reported in Panel A of Table 3. Consistent with the FF-3F model (Eun \& Huang, 2007), average monthly returns increase monotonically in relation to both inverse firm size and $\mathrm{B} / \mathrm{M}$. At the extremes, remarkably high returns are enjoyed by the smallest firms with high book-to-equity, and, in sharp contrast, the largest firms with lowest book-to-equity values have strongly negative returns. Thus, at

Table 3. Average equal-weighted monthly returns on double-sorted portfolios formed on size and

\begin{tabular}{|c|c|c|c|c|c|}
\hline \multirow{2}{*}{ Size } & \multirow{2}{*}{ Low } & \multicolumn{3}{|c|}{$\mathrm{B} / \mathrm{M}$ quintiles } & \multirow{2}{*}{ High } \\
\hline & & 2 & 3 & 4 & \\
\hline \multicolumn{6}{|c|}{ Panel A. Whole period } \\
\hline Small & 0.0036 & 0.0123 & 0.0193 & 0.0219 & 0.0417 \\
\hline 2 & -0.0012 & 0.0055 & 0.0131 & 0.0209 & 0.0342 \\
\hline 3 & -0.0046 & 0.0037 & 0.0077 & 0.0135 & 0.0253 \\
\hline 4 & -0.0085 & -0.0033 & 0.0042 & 0.0119 & 0.0231 \\
\hline Big & -0.0154 & -0.0092 & 0.0029 & 0.0062 & 0.0126 \\
\hline \multicolumn{6}{|c|}{ Panel B. Up-market period } \\
\hline Small & 0.0797 & 0.0851 & 0.0960 & 0.0988 & 0.1112 \\
\hline 2 & 0.0647 & 0.0769 & 0.0874 & 0.0941 & 0.1057 \\
\hline 3 & 0.0671 & 0.0746 & 0.0818 & 0.0827 & 0.0988 \\
\hline 4 & 0.0568 & 0.0662 & 0.0743 & 0.0896 & 0.0922 \\
\hline Big & 0.0522 & 0.0541 & 0.0688 & 0.0754 & 0.0806 \\
\hline \multicolumn{6}{|c|}{ Panel C. Down-market period } \\
\hline Small & -0.0864 & -0.0808 & -0.0836 & -0.0859 & -0.0769 \\
\hline 2 & -0.0806 & -0.0785 & -0.0757 & -0.0683 & -0.0575 \\
\hline 3 & -0.0810 & -0.0761 & -0.0684 & -0.0575 & -0.0534 \\
\hline 4 & -0.0720 & -0.0695 & -0.0643 & -0.0533 & -0.0497 \\
\hline Big & -0.0683 & -0.0645 & -0.0626 & -0.0596 & -0.0470 \\
\hline
\end{tabular}
book-to-market (B/M) quintiles from 1995 through 2008

Note: This table reports the average monthly equal-weighted returns on 25 portfolios formed on a double sort of size and B/M under overall, up-, and down-markets over the period 1995-2008. Following the methods of Fama and French, firm size is defined as market capitalization of tradable shares measured at the end of year $\mathrm{t}$; the $\mathrm{B} / \mathrm{M}$ ratio used to form portfolios in June of year $t$ is then book value of equity for the fiscal year ending in year $t-1$, divided by market capitalization of total outstanding shares at the end of December of year $t-1$. At the end of June of each year $t$, A-share stocks are sorted into quintiles based on June market capitalization of tradable shares; stocks are independently sorted into five $\mathrm{B} / \mathrm{M}$ quintile groups based on the breakpoints for $\mathrm{B} / \mathrm{M}$. Twenty-five size $-\mathrm{B} / \mathrm{M}$ portfolios are defined as the intersections of the five size and the five $\mathrm{B} / \mathrm{M}$ groups. Equal-weight monthly returns on the portfolios are calculated from July to the following June. When the excess market return is positive (negative), the market condition is defined as an up- (down-) market. Rf is the monthly return on one-year fixed deposits. Panels $\mathrm{A}, \mathrm{B}$ and $\mathrm{C}$ show the time-series average equal-weighted monthly portfolio returns under overall-market, up-market, and downmarket conditions, respectively. 
the outset, Panel A strongly confirms the FF value and size effects in the Chinese market.

Panels B and C of Table 3 set forth the outcomes separately for the up-market and down-market months, respectively. The basic idea here is to observe whether the out-performance of portfolios constructed on either firm size or $\mathrm{B} / \mathrm{M}$ might be viewed as a reward for their exposure to market risk. With regard to size, we observe that the portfolio returns are monotonically inversely related to size in the up-market months, but monotonically positively related to size in the downmarket months (firms of small capitalization outperform in up-markets and underperform in down-markets). This finding is consistent with the view that the size effect is a reward for bearing market risk. However, portfolios of higher $\mathrm{B} / \mathrm{M}$ firms have monotonically higher returns in both up-markets and down-markets. Thus a risk explanation based on exposure to market up-turns and down-turns is not appropriate in this setting. Noteworthy, also, is the fact that low $\mathrm{B} / \mathrm{M}$ firms underperform in (optimistic) growth markets. This evidence argues against their classification as "growth" stocks.

Table 4 presents the outcome of testing the FF-3F model on the data as in equation (1). The results are similar to the US experience. Specifically, (i) the estimated intercept terms are generally insignificantly different from zero, indicating "completeness" in the model; (ii) the estimated market betas are highly significant and all close to 1 , implying that asset pricing does not relate to differential sensitivities to the market, at least for this set of test portfolios; and (iii) the estimated SMB(HML) factor loadingdecreases (increases) monotonically with size $(\mathrm{B} / \mathrm{M})$, and with the exception of intermediate size and $B / M$ portfolios, the coefficients are statistically significant7. Thus, we conclude that the FF-3F model is applicable as a description of asset pricing in the Chinese markets, in a similar manner as it is for US markets.

\footnotetext{
In untabulated analysis, we also apply the regressions of equation (1) to up-market and down-market periods separately. We find that the intercepts are for the most part insignificantly different from zero, the estimated market betas remain close to 1 , and the returns on the size and $\mathrm{B} / \mathrm{M}$ portfolios retain a consistent relation to the SMB and HML factors. The explanatory power of the model as reflected by $\mathrm{R} 2$ is, however, greater when applied to the overall market.
}

Table 4. Fama-French three-factor model regressions over the period $1995-2008$

\begin{tabular}{|c|c|c|c|c|c|}
\hline \multirow{2}{*}{ Size } & \multirow{2}{*}{ Low } & \multicolumn{3}{|c|}{ Book-to-market (B/M) quintiles } & \multirow{2}{*}{ High } \\
\hline & & 2 & 3 & 4 & \\
\hline \multicolumn{6}{|c|}{$\mathbf{a}$} \\
\hline Small & -0.0001 & -0.0039 & 0.0012 & -0.0013 & 0.0004 \\
\hline 2 & 0.0089 & 0.0062 & 0.0015 & 0.0002 & 0.0075 \\
\hline 3 & 0.0054 & 0.0018 & 0.0042 & 0.0025 & -0.0018 \\
\hline 4 & 0.0095 & 0.0046 & 0.0043 & 0.0016 & 0.0024 \\
\hline Big & 0.0053 & 0.0008 & 0.0005 & 0.0047 & 0.0025 \\
\hline \multicolumn{6}{|c|}{ b } \\
\hline Small & 0.9436 & 0.9119 & 0.9684 & 0.8942 & 0.9143 \\
\hline 2 & 0.9489 & 0.9695 & 1.0172 & 0.9731 & 0.9822 \\
\hline 3 & 0.9152 & 0.8937 & 0.9592 & 1.0083 & 1.0312 \\
\hline 4 & 0.9688 & 0.9614 & 1.0034 & 0.9654 & 0.9789 \\
\hline Big & 0.9584 & 0.9137 & 0.9814 & 0.9500 & 0.9186 \\
\hline \multicolumn{6}{|c|}{ S } \\
\hline Small & 0.9162 & 0.8629 & 0.7013 & 0.6248 & 0.6655 \\
\hline 2 & 0.3270 & 0.4159 & 0.1771 & 0.2168 & 0.3788 \\
\hline 3 & 0.0140 & -0.0091 & 0.0031 & -0.0510 & -0.0404 \\
\hline 4 & -0.3537 & -0.4864 & -0.3717 & -0.2704 & -0.2429 \\
\hline Big & -0.7983 & -0.7167 & -0.8903 & -0.7414 & -0.6635 \\
\hline \multicolumn{6}{|c|}{ h } \\
\hline Small & -0.3299 & -0.1187 & 0.0746 & 0.1652 & 0.4916 \\
\hline 2 & -0.3426 & -0.0507 & 0.1881 & 0.3824 & 0.7463 \\
\hline 3 & -0.4298 & -0.0990 & 0.1680 & 0.3760 & 0.4901 \\
\hline 4 & -0.2848 & 0.0063 & 0.2598 & 0.3221 & 0.6081 \\
\hline Big & -0.4035 & 0.0534 & 0.2678 & 0.5903 & 0.8230 \\
\hline \multicolumn{6}{|c|}{$\begin{array}{c}\text { R-square } \\
\end{array}$} \\
\hline Small & 0.9307 & 0.9308 & 0.9241 & 0.8948 & 0.9400 \\
\hline 2 & 0.8783 & 0.8942 & 0.8917 & 0.9192 & 0.9218 \\
\hline 3 & 0.8648 & 0.8504 & 0.9018 & 0.9119 & 0.9500 \\
\hline 4 & 0.8978 & 0.8799 & 0.8910 & 0.9092 & 0.9621 \\
\hline Big & 0.9116 & 0.9063 & 0.9282 & 0.8960 & 0.9438 \\
\hline \multicolumn{6}{|c|}{$t(a)$} \\
\hline Small & -0.02 & -1.45 & 0.40 & -0.40 & 0.17 \\
\hline 2 & 2.43 & 1.83 & 0.44 & 0.07 & 2.39 \\
\hline 3 & 1.42 & 0.48 & 1.33 & 0.80 & -0.76 \\
\hline 4 & 2.85 & 1.26 & 1.23 & 0.52 & 1.25 \\
\hline Big & 1.59 & 0.25 & 0.17 & 1.42 & 1.07 \\
\hline \multicolumn{6}{|c|}{$\mathbf{t}(\mathbf{b})$} \\
\hline Small & 40.70 & 41.13 & 40.33 & 33.02 & 40.96 \\
\hline 2 & 31.47 & 34.55 & 34.82 & 40.33 & 36.62 \\
\hline 3 & 29.14 & 28.65 & 36.95 & 39.38 & 52.31 \\
\hline 4 & 34.05 & 32.08 & 34.74 & 38.65 & 59.84 \\
\hline Big & 34.81 & 35.95 & 41.61 & 34.78 & 46.94 \\
\hline \multicolumn{6}{|c|}{ t(s) } \\
\hline Small & 15.64 & 15.41 & 11.56 & 9.53 & 12.45 \\
\hline 2 & 4.29 & 5.87 & 2.40 & 3.61 & 5.82 \\
\hline 3 & 0.18 & -0.12 & 0.05 & -0.79 & -0.81 \\
\hline 4 & -5.05 & -6.43 & -5.10 & -4.29 & -5.89 \\
\hline Big & -11.48 & -11.16 & -14.94 & -10.77 & -13.89 \\
\hline \multicolumn{6}{|c|}{$\mathbf{t}(\mathbf{h})$} \\
\hline Small & -5.36 & -2.01 & 1.17 & 2.36 & 8.14 \\
\hline 2 & -4.28 & -0.68 & 2.42 & 6.07 & 10.04 \\
\hline 3 & -5.15 & -1.20 & 2.44 & 5.53 & 9.62 \\
\hline 4 & -3.86 & 0.08 & 3.39 & 4.85 & 14.15 \\
\hline Big & -5.52 & 0.79 & 4.27 & 8.07 & 14.74 \\
\hline
\end{tabular}

Note: This table reports estimates of the Fama and French three-factor model:

$R_{p t}-R_{f t}=a_{p t}+b_{p}\left(R_{M t}-R_{f t}\right)+s_{p} S M B_{t}+h_{p} H M L_{t}+\varepsilon_{p t}$ for monthly excess returns on 25 portfolios based on book-tomarket and size. The sample period is July 1995 - December 2008. The variables Rm-Rf, SMB and HML are calculated using the same methodology as Fama and French (1996). At the end of June of each year t, A-share stocks are allocated 
to two groups (S or B)based on whether their June market capitalization of tradable shares is below or above the median; stocks are allocated in an independent sort to three $\mathrm{B} / \mathrm{M}$ groups ( $\mathrm{L}, \mathrm{M}$, or $\mathrm{H}$ ) based on the breakpoints for the bottom $30 \%$, middle $40 \%$, and top $30 \%$ ofB $/ \mathrm{M}$. Six size-B/M portfolios $(\mathrm{S} / \mathrm{L}, \mathrm{SM}, \mathrm{S} / \mathrm{H}, \mathrm{B} / \mathrm{L}, \mathrm{BM}, \mathrm{B} / \mathrm{H})$ are defined as the intersections of the two size and the three B/M groups. Equally-weighted portfolios are calculated from July to the following June. SMB is the difference between the average of the returns on the three small-stock portfolios (SL, SM, and SH)and the average of the returns on the three big-stock portfolios (BL, BM, and $\mathrm{B} / \mathrm{H})$. $\mathrm{HML}$ is the difference between the average of the returns on the two high- $\mathrm{B} / \mathrm{M}$ portfolios $(\mathrm{S} / \mathrm{H}$ and $\mathrm{BH})$ and the average of the returns on the two low- $\mathrm{B} / \mathrm{M}$ portfolios (SL and $\mathrm{BL})$. The 25 size-B/ Mportfolios are formed similarly to the six size-B/M portfolios used to construct SMB and HML.

To explore the underlying price formation mechanism that might be sustaining the higher returns of high $\mathrm{B} / \mathrm{M}$ portfolios, we form quintile portfolios based on $\mathrm{B} / \mathrm{M}$, debt-to-equity (D/E), firm size, $\mathrm{E} / \mathrm{P}, \mathrm{C} / \mathrm{P}$ and $\mathrm{S} / \mathrm{P}$. Table 5 presents the results in terms of the returns and firm characteristics attached to the various portfolio types. Panel A confirms that higher $\mathrm{B} / \mathrm{M}$ values are associated with monotonically increasing returns. The observation of decreasing $\mathrm{D} / \mathrm{E}$ with increasing $\mathrm{B} / \mathrm{M}$ is notable on account of that a relation between $\mathrm{D} / \mathrm{E}$ and $\mathrm{B} / \mathrm{M}$ can be hypothesized as either positive or negative. For example, with (i) decreasing market stock prices, we anticipate both higher $\mathrm{B} / \mathrm{M}$ and higher $\mathrm{D} / \mathrm{E}$ ratios. However, with (ii) greater firm borrowing - implying higher debt in relation to equity - we may anticipate both a lower $\mathrm{B} / \mathrm{M}$ and a higher $\mathrm{D} / \mathrm{E}$ ratio. This is because when $\mathrm{B} / \mathrm{M}$ is a fraction, an equal reduction in both book (B) and market (M) equity values as an outcome of greater debt financing leads mathematically to a lower $\mathrm{B} / \mathrm{M}$ value8. Thus the relation of much-reduced $\mathrm{D} / \mathrm{E}$ values with higher $\mathrm{B} / \mathrm{M}$ values across quintiles 1-4 in Panel A is inconsistent with a higher $\mathrm{B} / \mathrm{M}$ for these portfolios as the outcome of suppressed market equity valuations, whereas the increase in $\mathrm{D} / \mathrm{E}$ between the 4th and 5 th is inconsistent with increasing $\mathrm{B} / \mathrm{M}$ ratios for these portfolios as the outcome of higher leverage. We note also that $\mathrm{E} / \mathrm{P}, \mathrm{C} / \mathrm{P}$ and $\mathrm{S} / \mathrm{P}$ are effectively monotonically increasing with $\mathrm{B} / \mathrm{M}$ and, thereby, also monotonically increasing with higher returns.
Panel B confirms the inverse relation between returns and firm size. Importantly, the panel also reveals that larger firms have much higher $\mathrm{E} / \mathrm{P}, \mathrm{C} / \mathrm{P}$ and $\mathrm{S} / \mathrm{P}$. This is intriguing because we now have the outcome that whereas higher $\mathrm{E} / \mathrm{P}$, $\mathrm{C} / \mathrm{P}$ and $\mathrm{S} / \mathrm{P}$ portfolios out-perform (see later panels), the variables are, nevertheless, positively associated with larger firm size portfolios, which of themselves underperform. We also note that the very smallest firms have a very high leverage.

Panel C reveals that stock returns have a fairly flat relation with $\mathrm{D} / \mathrm{E}$ (with a modest increase for quintile 5). As observed for Panel A, high leverage can be the outcome of either higher borrowing levels and/or a decline in stock valuations. In Panel $\mathrm{C}$, however, $\mathrm{B} / \mathrm{M}$ has a fairly stable relation with $\mathrm{D} / \mathrm{E}$ (with a decrease for quintile 5) which again suggests that the higher leverage ratios for these quintiles are unlikely to be the outcome of declines in market stock valuation.

In Panels $\mathrm{A}$ and $\mathrm{B}$, we have the outcome that firm performance indicators $(\mathrm{E} / \mathrm{P}, \mathrm{C} / \mathrm{P}$ and $\mathrm{S} / \mathrm{P}$ ) are increasing with both $\mathrm{B} / \mathrm{M}$ and firm size. However, returns are increasing with $\mathrm{B} / \mathrm{M}$ and decreasing with firm size. This leads to the question: Are returns increasing or decreasing with $\mathrm{E} / \mathrm{P}, \mathrm{C} / \mathrm{P}$ and $\mathrm{S} / \mathrm{P}$ ? Panels D-F establish that the former case holds (monotonically for $\mathrm{C} / \mathrm{P}$ and $S / P$ with an exception at the fourth quintile for $\mathrm{E} / \mathrm{P})$. We therefore have the observation that $\mathrm{E} / \mathrm{P}, \mathrm{C} / \mathrm{P}$ and $\mathrm{S} / \mathrm{P}$ (positively related to higher returns) are positively related to $\mathrm{B} / \mathrm{M}$ (which is also positively related to higher returns) and positively related to firm size (which is negatively related to higher returns). The fact that $\mathrm{B} / \mathrm{M}$, while highly correlated with $\mathrm{E} / \mathrm{P}, \mathrm{C} / \mathrm{P}$ and $\mathrm{S} / \mathrm{P}$, remains largely orthogonal with the firm size variable (panels $A$ and $B$ ) implies that $B / M$ presents an ideal proxy variable with which to capture "value" firms (with high E/P, C/P, and S/P) in combination with firm size as an explanatory variable.

8 To see this in terms of Panel A of Table 5, consider a firm with market equity (E) $=1$ unit and debt (D) $=2.9896$ units and book value $(B)=0.1643$ units as for $Q_{1}$ in the panel. To achieve a $D / E$ ratio $=0.9701$ as in $Q_{5}$, the firm would need to raise equity $E^{*}$ to replace debt so that $\left(2.9896-\mathrm{E}^{*}\right) /\left(1+\mathrm{E}^{*}\right)=0.9701$, implying $\mathrm{E}^{*}=1.025$ units. This would then change $\mathrm{B} / \mathrm{M}$ (from 0.1643$)$ to $(0.1643+1.025) /$ $(1+1.025)=0.59$; which compares closely with the $B / M$ value in $Q_{5}(0.6152)$. Thus higher $B / M$ values in Panel A are consistent with higher levels of leverage rather than as the outcome of under-pricing. The exception is that the leverage increase between the 4 th and 5 th quintiles implies that under-pricing of equity may be a part of the explanation for very high $\mathrm{B} / \mathrm{M}$. 
Table 5. Returns and firm characteristics for various characteristic sorts into quintile portfolios

\begin{tabular}{|c|c|c|c|c|c|c|}
\hline & $\mathrm{Q}_{0}$ & $\mathrm{Q}_{1}$ & $\mathrm{Q}_{2}$ & $\mathrm{Q}_{3}$ & $\mathrm{Q}_{4}$ & $\mathrm{Q}_{5}$ \\
\hline \multicolumn{7}{|c|}{ Panel A. Book-to-market (B/M) } \\
\hline $\mathrm{B} / \mathrm{M}$ & & 0.1643 & 0.2675 & 0.3454 & 0.4404 & 0.6152 \\
\hline Return & & 0.0153 & 0.0186 & 0.0213 & 0.0222 & 0.0243 \\
\hline $\mathrm{D} / \mathrm{E}$ & & 2.9896 & 1.2536 & 1.0137 & 0.9513 & 0.9701 \\
\hline Size & & $1,632.1$ & $1,289.7$ & $1,331.1$ & $1,229.5$ & $1,365.4$ \\
\hline $\mathrm{E} / \mathrm{P}$ & & -0.0030 & 0.0117 & 0.0176 & 0.0205 & 0.0194 \\
\hline $\mathrm{C} / \mathrm{P}$ & & 0.0200 & 0.0260 & 0.0297 & 0.0387 & 0.0521 \\
\hline S/P & & 0.2745 & 0.3587 & 0.4136 & 0.5203 & 0.7046 \\
\hline \multicolumn{7}{|c|}{ Panel B. Size } \\
\hline Size & & 380.9 & 596.9 & 839.9 & $1,269.5$ & $3,794.0$ \\
\hline Return & & 0.0237 & 0.0212 & 0.0190 & 0.0193 & 0.0184 \\
\hline $\mathrm{B} / \mathrm{M}$ & & 0.3038 & 0.3679 & 0.3930 & 0.3980 & 0.3678 \\
\hline $\mathrm{D} / \mathrm{E}$ & & 2.2585 & 1.2654 & 1.1542 & 1.0679 & 1.4345 \\
\hline$E / P$ & & -0.0155 & 0.0070 & 0.0155 & 0.0242 & 0.0349 \\
\hline $\mathrm{C} / \mathrm{P}$ & & 0.0121 & 0.0235 & 0.0348 & 0.0412 & 0.0547 \\
\hline $\mathrm{S} / \mathrm{P}$ & & 0.3680 & 0.4393 & 0.4812 & 0.4930 & 0.4881 \\
\hline \multicolumn{7}{|c|}{ Panel C. D/E } \\
\hline $\mathrm{D} / \mathrm{E}$ & & 0.2668 & 0.5710 & 0.8645 & 1.2840 & 4.1945 \\
\hline Return & & 0.0193 & 0.0206 & 0.0195 & 0.0204 & 0.0218 \\
\hline $\mathrm{B} / \mathrm{M}$ & & 0.3840 & 0.3716 & 0.3865 & 0.3765 & 0.3118 \\
\hline Size & & $1,299.9$ & $1,391.9$ & $1,323.1$ & $1,338.3$ & $1,527.7$ \\
\hline $\mathrm{E} / \mathrm{P}$ & & 0.0242 & 0.0233 & 0.0212 & 0.0158 & -0.0183 \\
\hline $\mathrm{C} / \mathrm{P}$ & & 0.0305 & 0.0332 & 0.0325 & 0.0375 & 0.0327 \\
\hline $\mathrm{S} / \mathrm{P}$ & & 0.2465 & 0.3578 & 0.4421 & 0.5346 & 0.6887 \\
\hline \multicolumn{7}{|c|}{ Panel D. E/P } \\
\hline$E / P$ & & 0.0066 & 0.0169 & 0.0251 & 0.0327 & 0.0542 \\
\hline Return & & 0.0170 & 0.0172 & 0.0183 & 0.0158 & 0.0234 \\
\hline $\mathrm{B} / \mathrm{M}$ & & 0.3662 & 0.3359 & 0.3444 & 0.3588 & 0.4301 \\
\hline $\mathrm{D} / \mathrm{E}$ & & 1.3041 & 1.1148 & 1.0486 & 1.1846 & 1.1860 \\
\hline Size & & 890.1 & $1,064.2$ & $1,408.5$ & $1,886.6$ & $2,384.4$ \\
\hline $\mathrm{C} / \mathrm{P}$ & & 0.0206 & 0.0267 & 0.0321 & 0.0376 & 0.0724 \\
\hline $\mathrm{S} / \mathrm{P}$ & & 0.3409 & 0.3783 & 0.4022 & 0.4589 & 0.6872 \\
\hline \multicolumn{7}{|c|}{ Panel E. C/P } \\
\hline $\mathrm{C} / \mathrm{P}$ & -0.0513 & 0.0088 & 0.0250 & 0.0430 & 0.0682 & 0.1446 \\
\hline Return & 0.0175 & 0.0180 & 0.0184 & 0.0205 & 0.0233 & 0.0256 \\
\hline $\mathrm{B} / \mathrm{M}$ & 0.3599 & 0.3245 & 0.3515 & 0.3796 & 0.4145 & 0.4588 \\
\hline $\mathrm{D} / \mathrm{E}$ & 1.0442 & 1.3537 & 1.2059 & 1.1481 & 1.3185 & 2.0461 \\
\hline Size & $1,118.3$ & $1,213.6$ & $1,456.0$ & $1,439.4$ & $1,557.2$ & $2,578.2$ \\
\hline $\mathrm{E} / \mathrm{P}$ & -0.0147 & 0.0066 & 0.0129 & 0.0171 & 0.0235 & 0.0314 \\
\hline $\mathrm{S} / \mathrm{P}$ & 0.4280 & 0.3565 & 0.3662 & 0.4198 & 0.5463 & 0.8100 \\
\hline \multicolumn{7}{|c|}{ Panel F. S/P } \\
\hline $\mathrm{S} / \mathrm{P}$ & & 0.0892 & 0.1985 & 0.3161 & 0.5031 & 1.1628 \\
\hline Return & & 0.0164 & 0.0189 & 0.0207 & 0.0213 & 0.0242 \\
\hline $\mathrm{B} / \mathrm{M}$ & & 0.2668 & 0.3196 & 0.3728 & 0.4126 & 0.4595 \\
\hline $\mathrm{D} / \mathrm{E}$ & & 1.7562 & 1.2227 & 1.8462 & 1.3033 & 1.8138 \\
\hline Size & & $1,670.6$ & $1,340.1$ & $1,180.5$ & $1,217.1$ & $1,467.0$ \\
\hline $\mathrm{E} / \mathrm{P}$ & & 0.0014 & 0.0120 & 0.0167 & 0.0152 & 0.0208 \\
\hline $\mathrm{C} / \mathrm{P}$ & & 0.0144 & 0.0222 & 0.0309 & 0.0399 & 0.0589 \\
\hline
\end{tabular}

Note: This table presents the average monthly returns and firm characteristics for portfolios sorted by B/M, Size, D/E, E/P, C/P, and S/P, for both Shanghai and Shenzhen A-share stocks from April 1995 through December 2008 (listed firms announce their annual reports in March/April). At the end of each April, quintile portfolios are formed on positive values of the variables, with a special portfolio formed for stocks with negative cash flows. This grouping procedure is repeated each year based on end-of-April values. $\mathrm{B} / \mathrm{M}$ is the ratio of book value of equity to market value of equity; size refers to market value of tradable A-shares (millions of Yuan); D/E is the leverage-debt-to-equity ratio; $\mathrm{E} / \mathrm{P}$ is the ratio of earnings to market value of equity; $\mathrm{C} / \mathrm{P}$ is the ratio of cash flow to market value of equity; and $\mathrm{S} / \mathrm{P}$ is the ratio of operating revenues to market value of equity. The market equity used to measure these accounting ratios is the market value of total outstanding shares at the end of each month in year t. For each of the variables, Panels A-F report monthly returns and explanatory variables on quintile portfolios sorted on B/M, size, D/E, E/P, C/P and $\mathrm{S} / \mathrm{P}$, respectively. Q1 contains stocks with the lowest positive values $(\mathrm{B} / \mathrm{M}$, Size, $\mathrm{D} / \mathrm{E}, \mathrm{E} / \mathrm{P}, \mathrm{C} / \mathrm{P}$ and $\mathrm{S} / \mathrm{P}) ; \mathrm{Q}_{5}$ contains stocks with the highest positive values (B/M, Size, D/E, E/P, C/P and S/P); stocks with negative cash flow are placed in $\mathrm{Q}_{0}$. 
Table 6. Average returns for double-sorted portfolios formed on total volatility, size, and book-tomarket ratio $(\mathrm{B} / \mathrm{M})$

\begin{tabular}{|c|c|c|c|c|c|c|}
\hline \multicolumn{7}{|c|}{ Panel A. Portfolios formed based on total volatility and size } \\
\hline \multirow{2}{*}{ Volatility } & \multicolumn{6}{|c|}{ Size quintiles } \\
\hline & & Small & 2 & 3 & 4 & Big \\
\hline & All & 0.0308 & 0.0200 & 0.0169 & 0.0112 & 0.0028 \\
\hline Low & 0.0192 & 0.0353 & 0.0222 & 0.0183 & 0.0168 & 0.0104 \\
\hline 2 & 0.0182 & 0.0323 & 0.0228 & 0.0176 & 0.0139 & 0.0048 \\
\hline 3 & 0.0175 & 0.0287 & 0.0229 & 0.0177 & 0.0105 & 0.0022 \\
\hline 4 & 0.0153 & 0.0273 & 0.0163 & 0.0190 & 0.0123 & 0.0017 \\
\hline High & 0.0104 & 0.0304 & 0.0151 & 0.0112 & 0.0018 & -0.0059 \\
\hline \multicolumn{7}{|c|}{ Panel B. Portfolios formed based on total volatility and B/M } \\
\hline & \multicolumn{6}{|c|}{$B / M$ quintiles } \\
\hline Volatility & & Low & 2 & 3 & 4 & High \\
\hline & All & -0.0030 & 0.0051 & 0.0136 & 0.0228 & 0.0415 \\
\hline Low & 0.0192 & 0.0026 & 0.0091 & 0.0165 & 0.0265 & 0.0406 \\
\hline 2 & 0.0182 & 0.0004 & 0.0090 & 0.0139 & 0.0243 & 0.0424 \\
\hline 3 & 0.0175 & -0.0026 & 0.0046 & 0.0138 & 0.0231 & 0.0475 \\
\hline 4 & 0.0153 & -0.0055 & 0.0050 & 0.0117 & 0.0233 & 0.0410 \\
\hline High & 0.0104 & -0.0108 & -0.0028 & 0.0115 & 0.0167 & 0.0362 \\
\hline
\end{tabular}

Notes: This table reports average monthly returns for two sets of double-sorted portfolios. The sample covers the period 19952008. Volatility is the variance of 24 monthly returns prior to the formation month. In Panel A, stocks are sorted into quintiles independently based on total volatility and size. The 25 portfolios are the intersections of the volatility quintiles and size quintiles. The portfolios are rebalanced each month. In Panel B, portfolios are formed based on total volatility and B/M.

Eun and Huang (2007) report that market risk is not priced in Chinese stock markets and that there is a negative relation between stock returns and stock volatility. We confirm their finding in Table 6 , which reports monthly returns over the preceding 24 months. We create two sets of double-sorted portfolios: $5 \times 5$ portfolios formed on volatility and size, and $5 \times 5$ portfolios formed on volatility and $\mathrm{B} / \mathrm{M}$. The results are presented in Panels A and B of the table. We first observe that controlling for volatility (looking across the rows), both smaller-size firms (Panel A) and higher book-to-market firms (Panel B) reveal consistently higher returns. Furthermore, controlling for both firm size (Panel A) and B/M (Panel B) (reading vertically in the columns), higher returns are generally associated with lower volatility.

Thus, the observed relation of stock returns in relation to $\mathrm{B} / \mathrm{M}$ and small firm size cannot be accounted for in terms of exposure to higher volatilities. This is confirmed in Table 7, where we relate portfolios formed on volatility to attributes of firm returns, size, $\mathrm{B} / \mathrm{M}, \mathrm{D} / \mathrm{E}$, and $\mathrm{E} / \mathrm{P}, \mathrm{C} / \mathrm{P}$ and $\mathrm{S} / \mathrm{P}$. The outcome is remarkably clear: Volatility is positively and monotonically related to $\mathrm{D} / \mathrm{E}$, but decreases monotonically in relation to stock returns, size (an exception is the $5^{\text {th }}$ quintile), $\mathrm{B} / \mathrm{M}$, and $\mathrm{E} / \mathrm{P}, \mathrm{C} / \mathrm{P}$ and $\mathrm{S} / \mathrm{P}$ in the portfolios. The above relations hold for both up- and down-market months. We also observe that higher returns of higher $\mathrm{B} / \mathrm{M}$ in the panels are negatively related to attributes of risk (volatility and financial leverage), and this trend is independent of whether the market is an up or a down-market phase. Thus, we confirm that higher stock returns cannot be attributed to market risk exposureor to either stock leverage or volatility. 
Table 7. Average characteristics for quintile portfolios formed on total volatility from 1995 through 2008

\begin{tabular}{|c|c|c|c|c|c|}
\hline \multicolumn{6}{|c|}{ Panel A. Whole period } \\
\hline & Q1 & Q2 & Q3 & Q4 & Q5 \\
\hline Volatility & 0.0117 & 0.0186 & 0.0268 & 0.0369 & 0.0706 \\
\hline Return & 0.0192 & 0.0182 & 0.0175 & 0.0153 & 0.0104 \\
\hline Size & $1,706.3$ & $1,292.5$ & $1,236.0$ & $1,316.8$ & $1,246.9$ \\
\hline $\mathrm{B} / \mathrm{M}$ & 0.4259 & 0.4079 & 0.3623 & 0.3284 & 0.2803 \\
\hline $\mathrm{D} / \mathrm{E}$ & 1.0045 & 1.2343 & 1.2434 & 1.4643 & 1.8851 \\
\hline $\mathrm{E} / \mathrm{P}$ & 0.0353 & 0.0225 & 0.0164 & 0.0067 & -0.0033 \\
\hline $\mathrm{C} / \mathrm{P}$ & 0.0471 & 0.0382 & 0.0306 & 0.0256 & 0.0225 \\
\hline $\mathrm{S} / \mathrm{P}$ & 0.5274 & 0.4841 & 0.4620 & 0.4078 & 0.3456 \\
\hline \multicolumn{6}{|c|}{ Panel B. Down-market period } \\
\hline & Q1 & Q2 & Q3 & Q4 & Q5 \\
\hline Volatility & 0.0113 & 0.0181 & 0.0263 & 0.0363 & 0.0691 \\
\hline Return & -0.0549 & -0.0611 & -0.0643 & -0.0704 & -0.0782 \\
\hline Size & $1,626.2$ & $1,217.1$ & $1,167.3$ & $1,241.2$ & $1,147.1$ \\
\hline $\mathrm{B} / \mathrm{M}$ & 0.4299 & 0.4177 & 0.3712 & 0.3383 & 0.2926 \\
\hline $\mathrm{D} / \mathrm{E}$ & 0.9457 & 1.1840 & 1.2116 & 1.3950 & 1.8459 \\
\hline $\mathrm{E} / \mathrm{P}$ & 0.0368 & 0.0241 & 0.0176 & 0.0085 & -0.0003 \\
\hline $\mathrm{C} / \mathrm{P}$ & 0.0439 & 0.0369 & 0.0301 & 0.0245 & 0.0237 \\
\hline $\mathrm{S} / \mathrm{P}$ & 0.5218 & 0.4855 & 0.4578 & 0.4051 & 0.3506 \\
\hline \multicolumn{6}{|c|}{ Panel C. Up-market period } \\
\hline & Q1 & Q2 & Q3 & Q4 & Q5 \\
\hline Volatility & 0.0121 & 0.0191 & 0.0273 & 0.0374 & 0.0720 \\
\hline Return & 0.0976 & 0.0947 & 0.0933 & 0.0925 & 0.0866 \\
\hline Size & $1,779.2$ & $1,360.9$ & $1,298.5$ & $1,385.4$ & $1,337.7$ \\
\hline $\mathrm{B} / \mathrm{M}$ & 0.4222 & 0.3990 & 0.3542 & 0.3194 & 0.2692 \\
\hline $\mathrm{D} / \mathrm{E}$ & 1.0579 & 1.2800 & 1.2723 & 1.5273 & 1.9208 \\
\hline $\mathrm{E} / \mathrm{P}$ & 0.0339 & 0.0211 & 0.0153 & 0.0051 & -0.0061 \\
\hline $\mathrm{C} / \mathrm{P}$ & 0.0500 & 0.0395 & 0.0310 & 0.0266 & 0.0214 \\
\hline S/P & 0.5324 & 0.4828 & 0.4657 & 0.4103 & 0.3409 \\
\hline
\end{tabular}

Notes: This table provides average monthly returns and fundamental characteristics for quintile portfolios formed on total volatility. The sample covers the period 1995-2008. Volatility is the variance of 24 monthly returns prior to the formation month. Quintile portfolios are rebalanced each month. Panels A, B and C give the average monthly returns and firm characteristics in the overall-sample, down-market, and up-market conditions, respectively.

\section{CONCLUSION}

We examine the application of the Fama and French three-factor model in Chinese stock markets over the sample period1995 to 2008 prior to the global financial crisis. We report a striking success for the model in relation to the firm size and $\mathrm{B} / \mathrm{M}$ factors introduced by the model. Thus, the stocks of smaller firms outperform the stocks of larger firms, which can be attributed to market risk since in down-markets, stocks of small firms underperform the stocks of larger firms. This is consistent with the economic reality that small firms tend to respond more dynamically to economic upturns while remaining more exposed to economic downturns. As in other world-wide studies, market beta risk does not appear to play an important role in asset pricing.

With regard to $\mathrm{B} / \mathrm{M}$, our main conclusions are as follows. The stocks of higher $\mathrm{B} / \mathrm{M}$ firms outperform the stocks of lower $\mathrm{B} / \mathrm{M}$ firms on aggregate as the model predicts. However, this observation applies in both up- and down-markets, which appears inconsistent with a risk-based explanation. We observe that portfolios of stocks with higher B/M largely subsume higher E/P, C/P and S/P ratios. Such portfolios are characterized by lower leverage and lower volatility. For these reasons, our findings argue decisively 
against a risk-based explanation for the higher returns recorded by portfolios with a higher B/M. We conclude that in relation to the $\mathrm{B} / \mathrm{M}$ factor, the Fama and French three-factor model succeeds as a form of "principal component analysis" whereby $\mathrm{B} / \mathrm{M}$, while remaining orthogonal to the small size factor, succeeds in capturing a range of additional variables (for example, $\mathrm{E} / \mathrm{P}, \mathrm{C} / \mathrm{P}$ and $\mathrm{S} / \mathrm{P}$ ) that are positively correlated with share price increases, but which are also positively correlated with firm size, thereby contradicting the small firm size effect.

\section{REFERENCES}

1. Allen, F., Qian, J., Qian, M., Zhao, M. (2008). A review of China's financial system and initiatives for the future (Working paper, Wharton Financial Institutions Center).

2. Beltratti, A., Bortolotti, B. (2006). The non-tradable share reform in the Chinese stock market (Working paper, University of Fondazi one Eni Enrico Mattei, Italy).

3. Chan, L., Hamao, Y., Lakonishok, J. (1991). Fundamentals and stock returns in Japan. Journal of Finance, 46, 1739-1789. Retrieved from http://www.jstor.org/stable/2328571

4. Drew, M. E., Naughton, T., Veeraraghavan, M. (2003). Firm size, book to market equity and security returns: evidence from the Shanghai Stock Exchange. Australian Journal of Management, 28, 119-140.

5. Eun, C. S., Huang, W. (2007). Asset pricing in China's domestic stock markets: Is there a logic? PacificBasin Finance Journal, 15, 434-451. https://doi.org/10.1016/j.pacfin.2006.11.002

6. Fama, E. F., French, K. R. (1992). The cross-section of expected stock returns. Journal of Finance, 47, 427-465.

7. Fama, E. F., French, K. R. (1993). Common risk factors in the returns on stocks and bonds. Journal of Financial Economics, 33, 3-56.

8. Fama, E. F., French, K. R. (1995). Size and book-to-market factors in earnings and returns. Journal of Finance, 50, 131-155.
9. Fama, E. F., French, K. R. (1996). Multifactor explanations of asset pricing anomalies. Journal of Finance, 51, 55-84.

10. Fama, E. F., French, K. R. (2015). A five-factor asset pricing model. Journal of Financial Economics, 116, 1-22. https://doi.org/10.1016/j. jfineco.2014.10.010

11. Kang, J., Liu, M., Ni, X. S. (2002). Contrarian and momentum strategies in the China stock market: 1993-2000. Pacific-Basin Finance Journal, 10, 243-265.

12. Lakonishok, J., Shleifer, A., Vishny, R. W. (1994). Contrarian investment, extrapolation, and risk. Journal of Finance, 49, 1541-1578.

13. Li, G. (2008). China’s stock market: inefficiencies and institutional implications. China \& World Economy, 16, 81-96.

14. Li, Y. M., Yan, D. Y., Greco, J. (2006). Market segmentation and price differentials between A-shares and $\mathrm{H}$-shares in the Chinese stock markets. Journal of Multinational Financial Management, 16, 232-248.

15. Lu, F, Balatbat, M., Czernkowski, R. (2008). The role of consideration in China's split share structure reform (Working paper, University of New South Wales).

16. Ma, S. G., Faff, R. (2007). Market conditions and the optimal IPO allocation mechanism in China. Pacific-Basin Finance Journal, 15, 121-139. https://doi.org/10.1016/j. pacfin.2006.06.001

17. Merton, R. C. (1973). An intertemporal capital asset pricing model. Econometrica, 41, 867-887.
18. Ng, L., Wu, F. (2006). Revealed stock preferences of individual investors: Evidence from Chinese equity markets. Pacific-Basin Finance Journal, 14, 175-192.

19. Ng, L., Wu, F. (2007). The trading behavior of institutions and individuals in Chinese equity markets. Journal of Banking \& Finance, 31, 2695-2710.

20. Poon, W., Firth, M., Fung, H. (1998). Asset pricing in segmented capital markets: Preliminary evidence from China-domiciled companies. Pacific-Basin Finance Journal, 6, 307-319.

21. Qi, D., Wu, W., Zhang, H. (2000). Shareholding structure and corporate performance of partially privatized firms: Evidence from listed Chinese companies. PacificBasin Finance Journal, 8, 587-610.

22. Ross, S. A. (1976). The Arbitrage Theory of capital asset pricing. Journal of Economic Theory, 13, 341-360.

23. Sun, Q., Chong, T. (2007). Determining the contributions to price discovery for Chinese crosslisted stocks. Pacific-Basin Finance Journal, 15, 140-153. https://doi. org/10.1016/j.pacfin.2006.07.002

24. Sun, Q., Tong, W.H.S. (2000). The effect of market segmentation on stock prices: The China syndrome. Journal of Banking and Finance, 24, 1875-1902.

25. Sun, Q., Tong, W.H.S. (2003). China share issue privatization: The extent of its success. Journal of Financial Economics, 70, 183-222. 